\title{
Antinociceptive activity of methanol extract of leaves of Solanum sisymbriifolium in heat and chemical-induced pain
}

\author{
Tania Nasrin ${ }^{1}$, Mahia Khandaker ${ }^{2}$, Saleha Akter $^{3}$, Mohammad Zafar Imam ${ }^{1 *}$ \\ ${ }^{1}$ Department of Pharmacy, Stamford University Bangladesh, 51 Siddeswari Road, Dhaka 1217, Bangladesh. \\ ${ }^{2}$ Department of Biotechnology, Bangabandhu Sheikh Mujibur Rahman Agricultural University, Salna, Gazipur 1706, Bangladesh. \\ ${ }^{3}$ Department of Pharmacy, Primeasia University, HBR Tower, Banani, Dhaka 1213, Bangladesh.
}

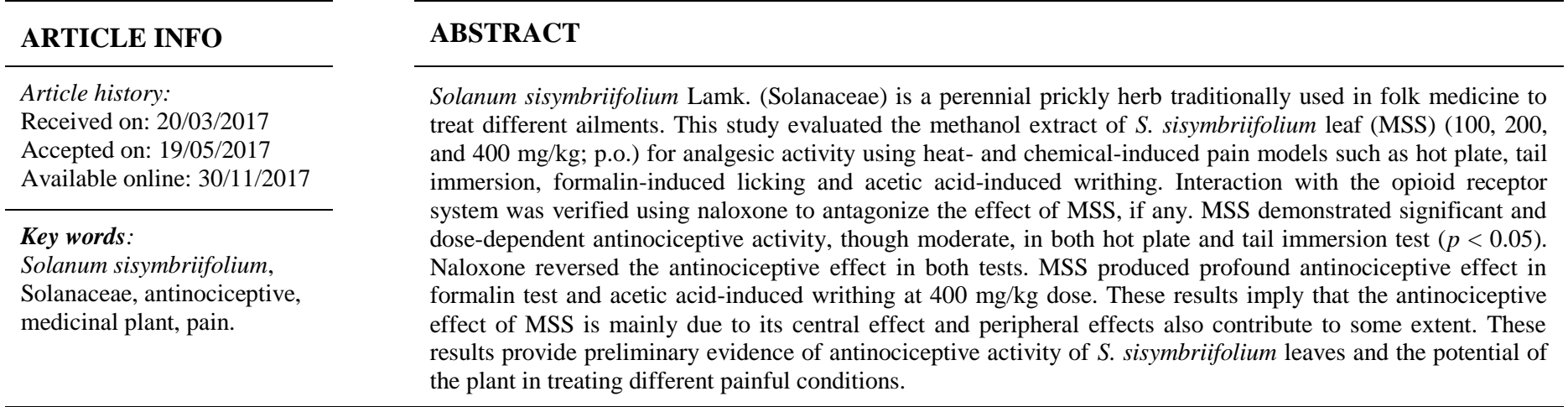

\section{INTRODUCTION}

Solanum sisymbriifolium Lamk. (Solanaceae) is a densely prickly perennial herb commonly known as sticky nightshade. The plant is traditionally used in the treatment of stomachache, remitting fever, hysteria (Uddin, 2016), respiratory tract infections, central nervous system (CNS) disorders and diarrhea (Ibarrola et al., 2000; Ferro et al., 2005). This plant is also used as diuretic, antihypertensive (Gonzales Torrez, 1992), emenagogue and fertility regulator (Martinez-Crovetto, 1981). Pharmacological investigations of different parts of $S$. sisymbriifolium have reported hypotensive (Ibarrola et al., 2000), analgesic (Shilpi et al., 2005), neuropharmacological and antidiarrheal activity (Apu et al., 2013). Phytochemical analyses confirmed isolation of a number of pharmacologically active compounds from the plant including solamine, solasodiene and solasodine (Mazumdar, 1984), neolignan, designated as

\footnotetext{
* Corresponding Author

Mohammad Zafar Imam, Department of Pharmacy, Stamford University Bangladesh, 51 Siddeswari Road, Dhaka 1217, Bangladesh.

Fax: +88-02-9355967-176; E-mail: zafarimam @ gmail.com.
}

sisymbrifolin, and carpesterol together with $\beta$-sitosterol and its $\beta$ D-glucoside, cuscohygrine, (Evans and Somanabandhu, 1980; Ferro et al., 2005), solacaproine, solamargine, and $\beta$-solamarine (Ferro et al., 2005) and isonuatigenin-3-O- $\beta$-solatriose (Ibarrola et al., 2000). Solasodine, a major alkaloid, isolated from the plant has demonstrated variety of biological activities including antifungal (Kusano et al., 1987), cytotoxic (Nakamura et al., 1996), hepatoprotective (Lin et al., 1988), antinociceptive (Basu and Lahiri, 1977; Pandurangan et al., 2010), anti-inflammatory (Pandurangan et al., 2011), anticonvulsant, CNS depressant (Chauhan et al., 2011) and antiatherosclerotic activity (Dixit et al., 1992). Solasodine is effective in skin tumor treatment (Cham et al., 1987; Cham et al., 1991). Nuatigenosido isolated from this plant has been reported to have cardiovascular effect (Ibarrola et al., 2006). The use of this plant in folk medicine in different ailments and analgesic report of whole plant extract by Shilpi et al. (2005) in acetic acid-induced writing motivated this study to evaluate the methanol extract of S. sisymbriifolium (MSS) leaf in different peripheral and central pain models in mice to find out whether the leaf is the major contributor in the effect as well the possible pathways involved in the analgesic effect. 


\section{MATERIALS AND METHODS}

\section{Plant material and extraction}

The leaves of $S$. sisymbriifolium were collected from Natore of Rajshahi Division, Bangladesh in January, 2011. Sarder Nasir Uddin, Senior Scientific Officer, Bangladesh National Herbarium identified the samples (DACB: 35424). Powdered dried leaves $(58 \mathrm{~g})$ were extracted with $350 \mathrm{ml}$ of methanol by Soxhlet apparatus at $50^{\circ} \mathrm{C}$ for $36 \mathrm{~h}$. Filtration was done using a sterile cotton filter, then the solvent was removed by rotary evaporator and 9.02 gm extract (Yield 15.55\%) was obtained. This extract was used for the phytochemical screening and animal studies.

\section{Chemicals and drugs}

Methanol (Merck, Germany), morphine sulphate (Gonoshasthaya Pharmaceuticals Ltd.), naloxone (Sigma, USA), diclofenac sodium (Square Pharmaceuticals Ltd.), formalin (Merck, Germany) and acetic acid (Merck, Germany).

\section{Animals}

Swiss albino male mice weighing 20-25 gm were used in the study (Animal Resources Branch of the International Center for Diarrhoeal Disease Research, Bangladesh (icddr,b)). The mice were housed in cages in group and had access to food and water ad libitum. Room temperature of the animal house was $25 \pm 2 \mathrm{C}$ and relative humidity was $55-60 \% .12 \mathrm{~h}$ light and $12 \mathrm{~h}$ dark cycle were maintained during the 14 day acclimatization period and throughout the experimental period. The Swiss Academy of Medical Sciences and the Swiss Academy of Sciences developed Ethical Principles and Guidelines for Scientific Experiments on Animals (1995) were followed for the animal welfare.

\section{Drugs and treatments}

Morphine sulphate, used as a positive standard, at the dose of $5 \mathrm{mg} / \mathrm{kg}$ body weight (b.w.) was injected intraperitoneally (i.p.) $15 \mathrm{~min}$ prior to hot plate, tail immersion and formalin test while diclofenac sodium was injected (i.p.) at the dose of 10 $\mathrm{mg} / \mathrm{kg}$ dose in acetic acid-induced writhing test. Vehicle controlled group was gavaged $0.9 \%$ saline water (vehicle) at the dose of 10 $\mathrm{ml} / \mathrm{kg}$. MSS was administered by oral gavage to mice at three different doses i.e., 100, 200, and $400 \mathrm{mg} / \mathrm{kg}$ b.w. I.P. injection of naloxone at $2 \mathrm{mg} / \mathrm{kg}$ dose was given $15 \mathrm{~min}$ before administering morphine or MSS in appropriate route to anticipate any possible involvement of MSS-opioid receptor interaction.

\section{Phytochemical screening}

Following standard qualitative phytochemical procedure described by Ghani (2003) alkaloids, carbohydrates, flavonoids, glucosides, glycosides, proteins, reducing sugars, saponins and steroids were tested in MSS.

\section{Acute toxicity test}

Three different mice groups $(n=5)$ received MSS orally at 500,1000 and $2000 \mathrm{mg} / \mathrm{kg}$ dose. Animals were closely observed for the next $72 \mathrm{~h}$ for any abnormality in behavior, any allergic response, morbidity and mortality (Walker et al., 2008).

\section{Antinociceptive tests \\ Hot plate test}

The test was performed following previously described method (Imam et al., 2012). Mice were fasted overnight with water given ad libitum. The animals were treated with morphine or MSS or vehicle and were placed on hot plate maintained at a temperature of $55 \pm 1^{\circ} \mathrm{C}$. To avoid any tissue damage in the paw of the mice $20 \mathrm{~s}$ was considered as cut off period. The response to the thermal stimuli as forepaw licking, withdrawal of the paw(s) or jumping was documented at 30, 60, 90, and $120 \mathrm{~min}$ after treatment.

\section{Tail immersion test}

Mice were pretreated with morphine or MSS and $\sim 2 \mathrm{~cm}$ of the tail was immersed in warm water maintained at $52 \pm 1{ }^{\circ} \mathrm{C}$. The latency period at 30,60, 90, and $120 \mathrm{~min}$ after treatment were documented (Toma et al., 2003). In this test, 20s was considered as cut off period to avoid tail tissue damage.

\section{Formalin test}

Formalin ( $20 \mu \mathrm{l}$ of $1.35 \%$ formalin) was injected into the sub-plantar region of the right hind paw of mice $30 \mathrm{~min}$ after MSS treatment and 15 min after injection of morphine. Paw licking was considered as nociceptive response and was documented at 0-5 min (early phase) and 15-25 min (late phase) after formalin injection (Coelho et al., 2005).

\section{Acetic acid-induced writhing test}

Morphine or MSS was administered in mice and then $0.7 \%$ acetic acid was injected i.p. after 15 and 30 min respectively $(10 \mathrm{ml} / \mathrm{kg})$ to induce writhing. The number of writhing was documented for $10 \mathrm{~min}$ starting after $5 \mathrm{~min}$ post treatment (Vogel, 2007).

\section{Statistical analysis}

The results are presented as mean \pm standard error of mean (SEM). The statistical analyses of the results were performed using ANOVA (SPSS 11.5). Dunnett's or Bonferroni's test was performed as post-hock test as appropriate. Differences between groups were considered significant at a level of $p<0.05$.

\section{RESULTS}

\section{Phytochemical screening}

Preliminary phytochemical screening of MSS detected the presence of alkaloids, glycosides, carbohydrates and saponins.

\section{Acute toxicity}

Oral administration of MSS up to $2000 \mathrm{mg} / \mathrm{kg}$ did not show any mortality, allergic manifestations or abnormality in behavior during the $72 \mathrm{~h}$ observation period in mice. 


\section{Hot Plate test}

MSS at 200 and $400 \mathrm{mg} / \mathrm{kg}$ significantly increased the latency to the thermal stimulus $(\mathrm{p}<0.01)$ dose dependently. MSS at $400 \mathrm{mg} / \mathrm{kg}$ dose produced strong antinociception. The effect of morphine at $5 \mathrm{mg} / \mathrm{kg}$ dose was highly significant $(\mathrm{p}<0.001)$. The effects of morphine and MSS were reversed by naloxone (Table $1)$.

\section{Tail immersion test}

The antinociceptive activity of MSS and standard drug morphine on the tail immersion test are given in Table 1. MSS at all three doses showed significant increase in latency and at $400 \mathrm{mg} / \mathrm{kg}$ dose showed highest increase in latency $(<0.001)$ which was reversed by naloxone. The effect of morphine was highly significant $(\mathrm{p}<0.001)$ and strongest among the treatment groups.

\section{Formalin test}

MSS at all doses $(100,200$, and $400 \mathrm{mg} / \mathrm{kg})$ reduced both early and late phase of paw licking induced by formalin (Table 2). However, the reduction in licking was significant $(p<0.05)$ only for morphine and MSS at $400 \mathrm{mg} / \mathrm{kg}$ doses.

\section{Acetic acid-induced writhing}

Oral administration of MSS at 100, 200, and $400 \mathrm{mg} / \mathrm{kg}$ doses reduced acetic acid-induced writhing compared to the control group (Table 2). However, the reduction was significant only at $400 \mathrm{mg} / \mathrm{kg}$ dose $(\mathrm{p}<0.05)$ and interestingly the effect was much stronger than that of diclofenac sodium.

Table 1: The antinociceptive effect of S. sisymbriifolium leaf, morphine, and reversal effect of naloxone in hot plate and tail immersion test.

\begin{tabular}{|c|c|c|c|c|c|c|c|}
\hline & \multirow[t]{2}{*}{ Treatment } & \multirow[t]{2}{*}{$\begin{array}{c}\text { Dose } \\
\text { (mg/kg) }\end{array}$} & \multicolumn{5}{|c|}{ Latency period (sec) } \\
\hline & & & $30 \mathrm{~min}$ & $45 \mathrm{~min}$ & $60 \mathrm{~min}$ & $90 \mathrm{~min}$ & $120 \mathrm{~min}$ \\
\hline \multirow{10}{*}{ 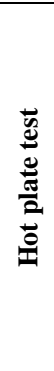 } & Vehicle & - & $2.20 \pm 0.07$ & $2.36 \pm 0.06$ & $2.37 \pm 0.14$ & $1.99 \pm 0.05$ & $2.59 \pm 0.09$ \\
\hline & Morphine & 5 (i.p.) & $11.63 \pm 0.13^{* * *}$ & $8.56 \pm 0.22 * * *$ & $9.41 \pm 0.20 * * *$ & $8.05 \pm 0.17 * * *$ & $4.56 \pm 0.18^{*}$ \\
\hline & MSS & 100 & $1.95 \pm 0.13$ & $3.15 \pm 0.19$ & $3.37 \pm 0.21$ & $2.53 \pm 0.12$ & $2.02 \pm 0.23$ \\
\hline & MSS & 200 & $2.17 \pm 0.12$ & $4.30 \pm 0.16^{*}$ & $4.32 \pm 0.12 *$ & $4.05 \pm 0.23 * *$ & $3.83 \pm 0.04$ \\
\hline & MSS & 400 & $3.26 \pm 0.16^{*}$ & $4.44 \pm 0.26^{* *}$ & $4.54 \pm 0.25^{* *}$ & $5.16 \pm 0.21 * * *$ & $4.05 \pm 0.22 *$ \\
\hline & NLX & 2 (i.p.) & $1.95 \pm 0.16$ & $2.62 \pm 0.11$ & $2.85 \pm 0.11$ & $3.54 \pm 0.14$ & $2.00 \pm 0.09$ \\
\hline & NLX + Morphine & $2+5$ & $3.54 \pm 0.19^{\mathrm{a}}$ & $4.23 \pm 0.14^{\mathrm{a}}$ & $4.06 \pm 0.22^{\mathrm{a}}$ & $3.06 \pm 0.22^{\mathrm{a}}$ & $2.79 \pm 0.13^{\mathrm{a}}$ \\
\hline & NLX + MSS & $2+100$ & $2.60 \pm 0.06$ & $2.10 \pm 0.15$ & $2.74 \pm 0.21$ & $3.60 \pm 0.18^{\mathrm{b}}$ & $2.68 \pm 0.17$ \\
\hline & NLX + MSS & $2+200$ & $2.43 \pm 0.16$ & $2.18 \pm 0.16^{\mathrm{c}}$ & $2.39 \pm 0.20^{\mathrm{c}}$ & $2.19 \pm 0.16^{\mathrm{c}}$ & $3.24 \pm 0.17$ \\
\hline & NLX + MSS & $2+400$ & $2.49 \pm 0.19$ & $2.86 \pm 0.21^{\mathrm{d}}$ & $2.53 \pm 0.18^{\mathrm{d}}$ & $3.58 \pm 0.21^{\mathrm{d}}$ & $2.63 \pm 0.20^{\mathrm{d}}$ \\
\hline \multirow{10}{*}{ 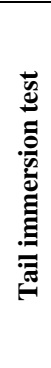 } & Vehicle & - & $2.03 \pm 0.09$ & $2.15 \pm 0.05$ & $2.35 \pm 0.09$ & $3.35 \pm 0.15$ & $2.41 \pm 0.11$ \\
\hline & Morphine & 5 (i.p.) & $8.00 \pm 0.25^{* * *}$ & $13.93 \pm 0.96 * * *$ & $12.41 \pm 0.53 * * *$ & $8.15 \pm 0.14^{* * *}$ & $2.42 \pm 0.09$ \\
\hline & MSS & 100 & $3.32 \pm 0.12$ & $3.37 \pm 0.15$ & $3.79 \pm 0.10$ & $5.00 \pm 0.24 *$ & $4.67 \pm 0.24 *$ \\
\hline & MSS & 200 & $4.69 \pm 0.14 * * *$ & $4.93 \pm 0.26$ & $5.52 \pm 0.20^{* *}$ & $6.33 \pm 0.08^{* * *}$ & $5.44 \pm 0.22 * *$ \\
\hline & MSS & 400 & $6.09 \pm 0.26^{* * *}$ & $5.28 \pm 0.10$ & $5.61 \pm 0.21 * *$ & $6.42 \pm 0.25^{* * *}$ & $6.63 \pm 0.44 * * *$ \\
\hline & NLX & 2 (i.p.) & $4.44 \pm 0.11$ & $3.40 \pm 0.16$ & $3.29 \pm 0.16$ & $3.99 \pm 0.11$ & $3.84 \pm 0.09$ \\
\hline & NLX + Morphine & $2+5$ & $3.28 \pm 0.10^{\mathrm{a}}$ & $4.79 \pm 0.17^{\mathrm{a}}$ & $4.54 \pm 0.14^{\mathrm{a}}$ & $4.04 \pm 0.18^{\mathrm{a}}$ & $3.52 \pm 0.22$ \\
\hline & NLX + MSS & $2+100$ & $3.86 \pm 0.07$ & $5.17 \pm 0.12^{\mathrm{b}}$ & $5.39 \pm 0.16^{\mathrm{b}}$ & $6.02 \pm 0.46$ & $4.92 \pm 0.40$ \\
\hline & NLX + MSS & $2+200$ & $3.03 \pm 0.17^{\mathrm{c}}$ & $2.41 \pm 0.16^{\mathrm{c}}$ & $2.30 \pm 0.10^{c}$ & $2.41 \pm 0.07^{\mathrm{c}}$ & $2.85 \pm 0.13^{\mathrm{c}}$ \\
\hline & NLX + MSS & $2+400$ & $3.68 \pm 0.09^{\mathrm{d}}$ & $3.76 \pm 0.14^{\mathrm{d}}$ & $4.72 \pm 0.09$ & $3.40 \pm 0.10^{\mathrm{d}}$ & $3.05 \pm 0.11^{\mathrm{d}}$ \\
\hline
\end{tabular}

Each value is presented as the mean \pm SEM $(\mathrm{n}=5)$. MSS $=$ Methanol extract of S. sisymbriifolium leaves; NLX = Naloxone. $* p<0.05 ; * * p<0.01 ; * * * p<0.001$ compared with the control group (Dunnett's test). ${ }^{a} p<0.001$ compared with the morphine group; ${ }^{b} p<0.05$ compared with the MSS 100 group; ${ }^{\mathrm{c}} p<0.05$ compared with the MSS 200 group; ${ }^{\mathrm{d}} p<0.01$ compared with the MSS 400 group (Bonferroni’s test).

Table 2: The antinociceptive effect of $S$. sisymbriifolium leaf extract and morphine in formalin-induced paw licking and acetic acid-induced writhing test in mice.

\begin{tabular}{|c|c|c|c|c|c|c|c|}
\hline \multirow[b]{2}{*}{ Treatment } & \multirow{2}{*}{$\begin{array}{c}\text { Dose } \\
(\mathrm{mg} / \mathrm{kg})\end{array}$} & \multicolumn{4}{|c|}{ Formalin-induced licking of the hind paw } & \multicolumn{2}{|c|}{ Acetic acid-induced writhing } \\
\hline & & $\begin{array}{c}\text { Early phase } \\
(0-5 \text { min })\end{array}$ & $\begin{array}{c}\% \\
\text { Inhibition }\end{array}$ & $\begin{array}{l}\text { Late phase } \\
(15-30 \text { min) }\end{array}$ & $\%$ Inhibition & $\begin{array}{c}\text { Number of } \\
\text { writhing }\end{array}$ & \% Inhibition \\
\hline Vehicle & 10 & $163.67 \pm 9.30$ & - & $153.67 \pm 12.1$ & - & $28.5 \pm 1.29$ & - \\
\hline Morphine & 5 & $50.00 \pm 3.28 *$ & 69.45 & $0.00 \pm 0.00 *$ & 100.00 & NT & NT \\
\hline Diclofenac sodium & 10 & NT & NT & NT & NT & $6.3 \pm 1.27 *$ & 77.89 \\
\hline MSS & 100 & $143.00 \pm 6.64$ & 12.63 & $139.00 \pm 7.88$ & 9.55 & $21.2 \pm 0.93$ & 25.61 \\
\hline MSS & 200 & $138.67 \pm 6.80$ & 15.28 & $110.00 \pm 6.03$ & 28.12 & $16.9 \pm 0.98$ & 40.70 \\
\hline MSS & 400 & $102.00 \pm 6.70 *$ & 37.68 & $60.30 \pm 8.26^{*}$ & 60.76 & $2.7 \pm 0.77 *$ & 90.53 \\
\hline
\end{tabular}

Each value is presented as the mean \pm SEM $(\mathrm{n}=5)$. $)$. MSS $=$ Methanol extract of $S$. sisymbriifolium leaves; NT $=$ not tested. * $p<0.05$ compared with the control group (Dunnett's test). 


\section{DISCUSSION}

The results of the present study indicate moderate but significant antinociceptive activity of MSS in particular at 400 $\mathrm{mg} / \mathrm{kg}$ dose. The effect was more profound in heat-induced pain models. It is believed that hot plate method demonstrates the supraspinal reflex mediated by $\mu_{1}$ and $\mu_{2}$-opioid receptors whereas the tail immersion test monitors the spinal reflex involving $\mu_{2^{-}}$and $\delta$-opioid receptors (Arslan and Bektas, 2010). These methods are, therefore, useful for screening molecules effective in spinal and supraspinal region. The increase in latency in these two tests by MSS indicates the modulation of central nervous system pain signaling. This hypothesis is further supported by the reversal of antinociception of MSS at all doses by naloxone in both hot plate and tail immersion test. Reversal of antinociceptive effect of MSS by naloxone raises the possibility of involvement of opioid receptor mediated effect at the spinal and supraspinal level which is predominant in case of morphine in both tests. Formalin-induced paw licking is a well-accepted chemical induced pain model that works in two divergent phases; early phase neurogenic pain due to direct stimulation of the sensory afferent fibers followed by inflammatory pain due to action of different inflammatory mediators (Parada et al., 2001; Le Bars et al., 2001). The effect of formalin can be consistently inhibited by typical analgesic and anti-inflammatory drugs like indomethacin, diclofenac sodium and morphine (Tjolsen et al., 1992). The results of our present study have shown that MSS reduced the number of paw licking significantly in neurogenic and inflammatory pain phases $(p<0.05)$. Acetic acid-induced release of prostaglandins, serotonin, bradykinin, histamine, TNF (some common endogenous mediators) in the peripheral tissue fluid is associated with the development of pain and writhing (Ikeda et al., 2001). The profound antinociceptive effect of MSS at $400 \mathrm{mg} / \mathrm{kg}$ dose in acetic acid-induced writhing test, therefore, implies that MSS may be involved in the inhibition of inflammatory mediators like cyclooxygenase, lipoxygenase and others which results in the interruption of signal transduction in primary afferent nociceptors. Solasodine which have already been shown antinociceptive, antiinflammatory and CNS depressant activity may play important role in MSS's antinociceptive effect along with other phytochemicals (Basu and Lahiri, 1997; Pandurangan et al., 2010; Pandurangan et al., 2011; Chauhan et al., 2011). The results of the present study underpin the preliminary basis of traditional use of $S$. sisymbriifolium in some painful conditions. It also presents the possibility of inhibition of inflammatory mediators as well as modulation of opioid system by compounds present in MSS. However, further research with isolated compounds is required to better understand the principal chemical entity/entities that contribute to the effect, the mechanisms involved and optimization of the preparation to be used.

\section{ACKNOWLEDGEMENT}

Financial support and sponsorship: None.
Conflict of Interests: There are no conflicts of interest.

\section{REFERENCES}

Apu AS, Matin M, Bhuyan SH, Hossain MF, Ireen K. Study of analgesic, neuropharmacological and anti-diarrheal activities of ethanol extract of Solanum sisymbriifolium fruits. Pharmacologia, 2013; 4:164169.

Arslan R, Bektas N. Antinociceptive effect of methanol extract of Capparis ovata in mice. Pharm Biol, 2010; 48:1185-1190.

Basu A, Lahiri SC. Some pharmacological actions of solasonine. Indian J Exp Biol, 1977; 15:285-289.

Cham BE, Daunter B, Evans RA. Topical treatment of malignant and premalignant skin lesions by very low concentrations of a standard mixture (BEC) of solasodine glycosides. Cancer Lett, 1991; 59:183-192.

Cham BE, Gilliver M, Wilson L. Antitumor effects of glycoalkaloids isolated from Solanum sodomaeum. Planta Med, 1987; 53:34-36.

Chauhan K, Sheth N, Ranpariya V, Parmar S. 2011. Anticonvulsant activity of solasodine isolated from Solanum sisymbriifolium fruits in rodents. Pharm Biol, 2011; 49:194-199.

Coelho LP, Reis PA, Castro FL, Gayer CRM, Lopes CS, Silva MCC, Sabino KCC, Todeschini AR, Coelho MGP. 2005. Antinociceptive properties of ethanolic extract and fractions of Pterodon pubescens Benth seeds. J Ethnopharmacol, 2005; 98:109-116.

Dixit VP, Verma M, Mathur NT, Mathur R, Sharma S. Hypocholesterolaemic and antiatherosclerotic effects of solasodine (C27H43O2N) in cholesterol fed rabbits. Phytother Res, 1992; 6:270-273.

Evans WC, Somanabandhu A. 1980. Nitrogen-containing nonsteroidal secondary metabolites of Solanum, Cyphomandra, Lycianthes and Margaranthus. Phytochem, 1980; 19:2351- 2356.

Ferro EA, Alvarenga NL, Ibarrola DA, Hellión-Ibarrola MC, Ravelo AG. A new steroidal saponin from Solanum sisymbriifolium roots. Fitoterapia, 2005; 76:577-579.

Ghani A. 2003. Medicinal Plants of Bangladesh: Chemical Constituents and Uses. $2^{\text {nd }}$ Ed. The Asiatic Society of Bangladesh, Dhaka, Bangladesh.

Gonzales Torrez DM. 1992. Catalog of Medicinal Plants (with Useful Food Values) Used in Paraguay. Asuncion, El Pais.

Ibarrola DA, Hellion-Ibarrola MC, Alvarenga NL, Ferro EA, Hatakeyama N, Shibuya N, Yamazaki M, Momose Y, Yamamura S, Tsuchida K. Cardiovascular action of Nuatigenosido from Solanum sisymbriifolium. Pharm Biol, 2006; 44:378-381.

Ibarrola DA, Hellión-Ibarrola MC, Montalbetti Y, Heinichen O, Alvarenga N, Figueredo A, Ferro EA. Isolation of hypotensive compounds from Solanum sisymbriifolium Lam. J Ethnopharmacol, 2000; 70:301-307.

Ikeda Y, Ueno A, Naraba H, Oh-ishi S. Involvement of vanilloid receptor VR1 and prostanoids in the acid acid-induced writhing responses of mice. Life Sci, 2001; 69:2911-2919.

Imam MZ, Nahar N, Akter S, Rana MS. Antinociceptive activity of methanol extract of flowers of Impatience balsamina. J Ethnopharmacol, 2012; 142:804-810.

Kusano G, Takahashi A, Sugiyama K, Nozoe S. Antifungal properties of Solanum alkaloids. Chem Pharm Bull, 1987; 35:4862-4867.

Le Bars D, Gozariu M, Cadden SW. Animal models of nociception. Pharmacol Rev, 2001; 53:597-652.

Lin CN, Chung MI, Gan KH. Novel antihepatotoxic principles of Solanum incanum. Planta Med, 1988; 54:222.

Martinez-Crovetto R. Fertility-regulating plants used in popular medicine in Northeastern Argentina. Parodiana, 1981; 1:97-117.

Mazumdar BC. Steroidal sapogenins in two wild species of Solanum. Sci Cult, 1984; 50:122-123.

Nakamura T, Komori C, Lee Y, Hashimoto F, Yahara S, Nohara T, Ejima A. Cytotoxic activities of Solanum steroidal glycosides. Biol Pharm Bull, 1996; 19:564-566. 
Pandurangan A, Khosa RL, Hemalatha S. 2011. Antiinflammatory activity of an alkaloid from Solanum trilobatum on acute and chronic inflammation models. Nat Prod Res, 2011; 25:1132-1141.

Pandurangan A, Khosa RL, Hemalatha S. Antinociceptive activity of steroid alkaloids isolated from Solanum trilobatum Linn. J Asian Nat Prod Res, 2010; 12:691-695.

Parada CA, Tambeli CH, Cunha FQ, Ferreira SH. The major role of peripheral release of histamine and 5-hydroxytryptamine in formalin-induced nociception. Neurosci, 2001; 102:937-944.

Shilpi JA, Rouf R, Sarker MAM, Qamrunnahar, Ferdous MM, Uddin SJ. Antinociceptive activity of methanol extract of Solanum sisymbrifolium Lamk. Pak J Biol Sci, 2005; 8:1123-1125.

Tjolsen A, Berge OG, Hunskaar S, Rosland JH, Hole K. The formalin test: An evaluation of the method. Pain, 1992; 51:5-17.

Toma W, Graciosa JS, Hiruma-Lima CA, Andrade FDP, Vilegas W, Brita ARMS. Evaluation of the analgesic and antiedematogenic activities of Quassia amara bark extract. J Ethnopharmacol, 2003; 85:19-23.

Uddin SN. 2006. Traditional uses of ethnomedicinal plants of the Chittagong Hill Tracts. Bangladesh National Herbarium, Dhaka, Bangladesh.

Vogel HG. 2007. Drug Discovery and Evaluation: Pharmacological Assays. Springer, Berlin, H.G.

Walker CIB, Trevisan G, Rossato MF, Franciscato C, Pereira ME, Ferreira J, Manfron MP. Antinociceptive activity of Mirabilis jalapa in mice. J Ethnopharmacol, 2008; 120:169-175.

\section{How to cite this article:}

Nasrin T, Khandaker M, Akter S, Imam MZ Antinociceptive activity of methanol extract of leaves of Solanum sisymbriifolium in heat and chemical-induced pain. J App Pharm Sci, 2017; 7 (11): 142-146. 